\title{
Ameliorative Effect of Thymus Oil on Paracetamol Induced Hepato-Renal Toxicity: A Biochemical, Antioxidant and Histopathological Studies
}

\author{
Ashraf Elkomy, Mohamed Aboubakr* and Lamis Ashraf \\ Department of pharmacology, Faculty of Veterinary Medicine, Benha University, 13736 Moshtohor,Toukh, Qaliobiya, Egypt
}

Submission: October 27, 2017; Published: November 27, 2017

*Corresponding author: Mohamed Aboubakr, Pharmacology Department, Faculty of Veterinary Medicine, Benha University, 13736 Moshtohor,Toukh, Qaliobiya, Egypt, Email: mohamed.aboubakr@fvtm.bu.edu.eg

\begin{abstract}
Hepato-renal protective effects of thymus oil against paracetamol toxicity were investigated in rats. Thirty five male rats were divided into seven groups as following: Group I was administered saline solution (for 30 days). Group II was administered saline solution in addition to a single-dose of paracetamol at a dose of $2 \mathrm{~g} / \mathrm{kg} \mathrm{BW}, 1 \mathrm{~h}$ after last dose of saline. Groups III and IV were administered thymus oil (250 and $500 \mathrm{mg} /$ kg BW, respectively. Groups V, VI and VII received Thymus oil $(250,500 \mathrm{mg} / \mathrm{kg})$ and silymarin $(100 \mathrm{mg} / \mathrm{kg})$, respectively, once for 30 consecutive days followed by a single oral dose of paracetamol $(2 \mathrm{~g} / \mathrm{kg}), 1 \mathrm{~h}$ after the last thymus oil and silymarin dose. Paracetamol induced disturbance in hepatic and renal functions and injured the hepatic and renal cells evident from depletion of catalase (CAT) and super oxide dismutase (SOD) activities along with increased level of malondialdehyde (MDA). Co-administration of thymus oil with paracetamol kept the studied biochemical parameters within normal ranges and prevented lipid peroxidation and oxidative stress induced by paracetamol. Our findings concluded that thymus oil possessed hepato-renal protective activity against paracetamol induced toxicity in rats and this protection may involve the reduction of oxidative stress.
\end{abstract}

Keywords: Thymus oil; Hepato-renal; toxicity; Protective; Paracetamol; Rats

\section{Introduction}

The use of plants in medicine is an age-long practice in various parts of the globe for both preventive and curative. Today, it is estimated that about $80 \%$ of the world population relies on botanical preparations as medicine to meet their health [1]. Liver diseases are considered as a major public health problem around the world due to their potentiality to cause morbidity and mortality [2]. About more than two million people in the world die annually from liver-related disorders [3]. Kidneys are important organs that play a role in all humans and animals. The general functions of the kidneys are to regulate blood pressure, acid-base balance, electrolyte balance and extracellular fluid volume. They also eliminate substances from the body including metabolic products, various toxins and other foreign substances such as drugs, pesticides and food additives [4].

Paracetamol (PRM); is a widely analgesic medication in many countries. An overdose of paracetamol is a frequent reason for liver and renal toxicity and possible death [5]. PRM is metabolized in the liver by cytochrome P450 to N-acetyl-pbenzoquinone imine (NAPQI). NAPQI reacts with glutathione (GSH), therefore overdoses of paracetamol may result in a depletion of hepatocellular GSH [6]. GSH exhaustion will cause NAPQI to binds with cellular proteins leading to mitochondrial dysfunction, oxidative stress, lipid peroxidation, DNA fragmentation, massive hepatocyte necrosis, liver damage and death [7]. Paracetamol is a common analgesic and antipyretic drug which is safe in therapeutic doses but can produce lifethreatening hepatic and renal damages in man, rats and mice with toxic doses $[8,9]$. Protection against paracetamol induced hepato-renal toxicity has been used as a test for potential protective activity by several investigators [10]

Thyme possesses various beneficial effects, e.g., antiseptic, antimicrobial, bactericidal, anthelmintic, antioxidant properties and it has recently suggested as a natural replacement for synthetic antioxidant [11]. Thyme is an excellent source of iron, manganese and vitamin $\mathrm{K}$. It is also a very good source of calcium [12]. The stimulating action on the nervous system makes thymus a brilliant remedy for mental as well as physical fatigue, anxiety, alleviating tension and sleeplessness. The herb is also effective in treating depression or mood changes [13]. The therapeutic efficacy of thyme depends on its contents of 
flavonoids, carvacrol, thymol, eugenol, aliphatic phenols as well as saponins, tetramethoxylated flavones and luteolin $[14,15]$.

In this study we evaluated the level of protection of thymus oil against the hepato-renal toxicity of paracetamol in rats. Markers of damage measured in the serum of rats included AST (aspartate aminotransferase) and ALT (alanine aminotransferase) (markers of liver function) as well as blood urea nitrogen and creatinine (markers of renal function). Superoxide dismutase (SOD), catalase (CAT) and malondialdehyde (MDA) (markers of oxidative damage) were measured in liver and kidney tissue homogenates. Pathological examination of those organs was also performed.

\section{Materials and Methods}

\section{Chemicals}

Paracetamol was purchased from EIPICO Co., 10th of Ramadan City, Egypt. Thymus oil was purchased from Wadi Al Nahil Co. (Riyadh, Kingdom of Saudi Arabia). Silymarin was purchased from Medical Union Pharmaceuticals (MUP) Co., Egypt. All the diagnostic kits were obtained from Biodiagnostic Co., Giza, Egypt.

\section{Experimental Animals}

Thirty five Male Wistar rats (170-195 g) were obtained from the Animal House, Faculty of Veterinary Medicine, Benha University, Egypt. They were fed on a standard pellet diet and tap water was provided ad libitum and were kept in stainless stell cages in a clean ventilated room at $40-60 \%$ relative humidity and at room temperature $22-25^{\circ} \mathrm{C}$. Prior to experimental use, rats were acclimatized to the environment for two week. Animal facilities and management and the specific manipulations within the experimental protocol were conducted as stipulated in the Guide for Care and Use of Laboratory Animals Guidelines of the National Institutes of Health (NIH), and approved by the research ethical committee of the Faculty of Veterinary Medicine, Benha University, Egypt.

\section{Experimental design}

Following experimental acclimation, rats were weighed and randomly allocated into seven groups, each consisting of five rats. Treatments were carried out for 30 days. Group I (control) was administered saline solution orally each day for the duration of treatment. Group II was administered saline solution orally each day for the duration of treatment in addition to a singledose of paracetamol at a dose of $2 \mathrm{~g} / \mathrm{kg} \mathrm{BW}$ [16], $1 \mathrm{~h}$ after last dose of saline solution administration. Groups III and IV were administered thymus oil orally each day for the duration of treatment at a dose of 250 and $500 \mathrm{mg} / \mathrm{kg} \mathrm{BW}$ [17], respectively. Groups V, VI and VII received Thymus oil $(250,500 \mathrm{mg} / \mathrm{kg}$ ) and silymarin (100 mg/kg) [18], respectively, once daily for 30 consecutive days followed by a single oral administration of paracetamol $(2 \mathrm{~g} / \mathrm{kg}), 1 \mathrm{~h}$ after the last thymus oil and silymarin dose administration.

\section{Blood and Tissue Samples}

After $48 \mathrm{~h}$ of paracetamol administration, rats were anesthetised by diethyl ether. Blood samples from each rat was collected by puncturing retro-orbital plexus in sterilized dry centrifuge tube and kept for $30 \mathrm{~min}$ at room temperature in a slanted position to coagulate before centrifugation at 1200 $\mathrm{x} g$ for 20 min to obtain serum, which was preserved at $-80 \mathrm{oC}$ until further use in biochemical investigations. After blood collection, the animals of all groups were sacrificed by cervical decapitation and liver and kidneys were excised from each rat and washed with physiological saline. A $0.5 \mathrm{~g}$ section of each tissue was homogenized in $5 \mathrm{ml}$ phosphate buffer $\mathrm{pH} 7.4 \mathrm{using}$ an electrical homogenizer and maintaining the sample on ice. Tissue homogenates were centrifuged at $1200 \mathrm{x}$ g for $20 \mathrm{~min}$ at $4 \mathrm{oC}$. The resulting supernatants were isolated and stored at $-80 \mathrm{oC}$ until further use in assessment of oxidative-stress biomarkers in hepatic and renal tissues. Remaining liver and kidney tissue were immediately preserved in $10 \%$ formalin for histopathogical investigations.

\section{Assessment of Serum Biochemical Parameters}

The preserved sera were utilized for the estimation of hepatic and renal injury biomarkers. Levels of serum aspartate aminotransferase (AST) and alanine aminotransferase (ALT) were estimated using the technique described by [19], total bilirubin [20], total protein [21], albumin [22], glucose [23], creatinine [24] and urea [25]. Total cholesterol, HDL-cholesterol and triglycerides levels were estimated according to [26], while, LDL levels were calculated by the method of [27].

\section{Assessment of Antioxidant Status}

Catalase (CAT) and superoxide dismutase (SOD) were evaluated by the techniques of [28,29], respectively. Malondialdehyde (MDA) concentration was measured according to the method of [30].

\section{Histopathological Study}

The fixed tissues were processed routinely using a standard histological procedure: tissues were washed in 70\% alcohol, dehydrated through a series of ascending ethanol percentage washes until $100 \%$ ethanol was reached, cleared in xylene, infiltrated with soft paraffin (melting point $=60 \mathrm{oC}$ ), and finally embedded into molten paraffin wax. The resulting paraffin blocks were sectioned at 5-7 mm thickness using a rotatory microtome. The paraffin sections were dewaxed in xylene and then rehydrated through a series of descending ethanol percentage washes. The sections were initially treated with either Harris hematoxylin and eosin (H\&E) stain, for assessment of histopathological changes [31].

\section{Statistical Analysis}

The data were expressed as mean \pm SE of studied groups using the analysis of variance test (one way ANOVA) followed by Duncan's multiple range test to determine the differences 
between the averages at 0.05 significance value. All analysis were performed by Statistical Package for Social science Software (SPSS (16) software (SPSS Inc., Chicago, USA).

\section{Results}

\section{Serum Biochemical Analysis}

The activities of tranaminases and the level of total bilirubin and albumin are shown in Table 1. The level of AST, ALT and total bilirubin increased significantly in paracetamol treated rats (Group II), while the content of albumin decreased significantly when compared with control (Group I). Co-treatment with thymus oil and paracetamol (Groups V and VI) reduced the concentration of AST, ALT and total bilirubin while increasing albumin content significantly. Also, rats administered thyums oil alone $(500 \mathrm{mg} / \mathrm{kg}$ ) revealed significant changes in the mentioned parameters as compared to paracetamol treated group.

Indices of kidney functions were displayed in Table 2. The levels of creatinine, urea and glucose were significantly increased in serum of rats received paracetamol, while the content of total protein decreased significantly as compared to control group. The co-treatment with thymus oil recorded significant decrement in creatinine, urea and glucose, while increasing total protein content significantly in comparison with paracetamol treated group.

Table 1: The effect of thymus oil (250 and $500 \mathrm{mg} / \mathrm{kg} \mathrm{BW})$ and/or paracetamol (2 $\mathrm{g} / \mathrm{kg}$ BW) treated groups on biomarkers of hepatic damage.

\begin{tabular}{|c|c|c|c|c|}
\hline Groups & $\operatorname{AST}(\mathrm{U} / \mathrm{L})$ & $\operatorname{ALT}(\mathrm{U} / \mathrm{L})$ & T.bilirubin (mg/dl) & $\operatorname{Albumin}(\mathrm{g} / \mathrm{dl})$ \\
\hline Control & $78.52 \pm 2.77^{c}$ & $46.91 \pm 1.98^{d}$ & $0.60 \pm 0.04^{\mathrm{bc}}$ & $1.91 \pm 0.02^{\mathrm{a}}$ \\
\hline Paracetamol (2 g/kg) & $153.33 \pm 6.48^{\mathrm{a}}$ & $97.96 \pm 4.87^{\mathrm{a}}$ & $0.91 \pm 0.05^{\mathrm{a}}$ & $1.04 \pm 0.02^{\mathrm{c}}$ \\
\hline Thyme oil (250 mg/kg) & $72.19 \pm 2.34^{\mathrm{cd}}$ & $42.61 \pm 1.55 \mathrm{~d}^{\mathrm{e}}$ & $0.55 \pm 0.05^{\mathrm{cd}}$ & $1.77 \pm 0.07^{\mathrm{a}}$ \\
\hline Thyme oil (500 mg/kg) & $64.71 \pm 2.14^{\mathrm{d}}$ & $35.15 \pm 1.69^{\mathrm{e}}$ & $0.45 \pm 0.02^{\mathrm{d}}$ & $1.47 \pm 0.06^{\mathrm{b}}$ \\
\hline $\begin{array}{c}\text { Thyme oil (250 mg/ } \\
\mathrm{kg})+ \text { Paracetamol (2 g/kg) }\end{array}$ & $119.19 \pm 6.72^{b}$ & $84.53 \pm 3.95^{b}$ & $0.85 \pm 0.02^{\mathrm{a}}$ & $1.19 \pm 0.05^{\mathrm{c}}$ \\
\hline $\begin{array}{c}\text { Thyme oil (500 mg/ } \\
\mathrm{kg})+ \text { Paracetamol }(2 \mathrm{~g} / \mathrm{kg})\end{array}$ & $78.52 \pm 2.77^{c}$ & $61.90 \pm 3.08^{c}$ & $0.70 \pm 0.04^{\mathrm{b}}$ & $1.36 \pm 0.04^{\mathrm{b}}$ \\
\hline $\begin{array}{c}\text { Silymarin (100 mg/ } \\
\mathrm{kg})+ \text { Paracetamol (2 g/kg) }\end{array}$ & $84.10 \pm 1.34^{c}$ & $51.31 \pm 1.06^{\mathrm{d}}$ & $0.62 \pm 0.02 b^{c}$ & $1.83 \pm 0.05^{\mathrm{a}}$ \\
\hline
\end{tabular}

Values are represented as Mean \pm SE $(n=5)$. Means within the same column carrying different superscripts are significant at $(p<0.05)$.

AST, aspartate aminotransferase; ALT, alanine aminotransferase.

Table 2: The effect of thymus oil (250 and $500 \mathrm{mg} / \mathrm{kg} \mathrm{BW})$ and/or paracetamol ( $2 \mathrm{~g} / \mathrm{kg} \mathrm{BW})$ treated groups on biomarkers of renal damage.

\begin{tabular}{|c|c|c|c|c|}
\hline Groups & Creatinine (mg/dl) & Urea (mg/dl) & Glucose (mg/dl) & T.protein (g/dl) \\
\hline Control & $0.97 \pm 0.01^{\mathrm{e}}$ & $44.25 \pm 1.76^{\mathrm{de}}$ & $141.71 \pm 3.18^{\mathrm{d}}$ & $4.87 \pm 0.04^{\mathrm{a}}$ \\
\hline Paracetamol (2 g/kg) & $2.06 \pm 0.07^{\mathrm{a}}$ & $83.54 \pm 2.70^{\mathrm{a}}$ & $252.71 \pm 2.95^{\mathrm{a}}$ & $3.48 \pm 0.11^{\mathrm{e}}$ \\
\hline Thyme oil (250 mg/kg) & $0.91 \pm 0.02^{\mathrm{e}}$ & $41.84 \pm 2.36^{\mathrm{e}}$ & $128.27 \pm 5.13^{d}$ & $4.49 \pm 0.19^{\mathrm{ab}}$ \\
\hline Thyme oil (500 mg/kg) & $0.75 \pm 0.03^{f}$ & $32.78 \pm 0.33^{\mathrm{f}}$ & $113.4 \pm 3.29^{\mathrm{e}}$ & $4.02 \pm 0.07^{\mathrm{cd}}$ \\
\hline $\begin{array}{c}\text { Thyme oil (250 mg/ } \\
\mathrm{kg})+ \text { Paracetamol (2 g/kg) }\end{array}$ & $1.83 \pm 0.02^{\mathrm{b}}$ & $73.91 \pm 4.73^{\mathrm{b}}$ & $202.72 \pm 5.19^{b}$ & $3.63 \pm 0.21^{\text {de }}$ \\
\hline $\begin{array}{c}\text { Thyme oil (500 mg/ } \\
\mathrm{kg})+ \text { Paracetamol (2 g/kg) }\end{array}$ & $1.38 \pm 0.02^{\mathrm{c}}$ & $64.81 \pm 2.19 \underline{c}$ & $188.65 \pm 6.50^{c}$ & $4.15 \pm 0.09^{b c}$ \\
\hline $\begin{array}{c}\text { Silymarin (100 mg/ } \\
\mathrm{kg})+ \text { Paracetamol (2 g/kg) }\end{array}$ & $1.13 \pm 0.06^{\mathrm{d}}$ & $50.45 \pm 3.20^{\mathrm{d}}$ & $133.04 \pm 4.89^{\mathrm{d}}$ & $4.43 \pm 0.13^{\mathrm{bc}}$ \\
\hline
\end{tabular}

Values are represented as Mean $\pm S E(n=5)$. Means within the same column carrying different superscripts are significant at $(p<0.05)$. Table 3: The effect of thymus oil ( 250 and $500 \mathrm{mg} / \mathrm{kg} \mathrm{BW})$ and/or paracetamol ( $2 \mathrm{~g} / \mathrm{kg}$ BW) treated groups on lipid profile parameters.

\begin{tabular}{|c|c|c|c|c|}
\hline Groups & Cholesterol (mg/dl) & $\begin{array}{c}\text { Triglycerides } \\
\text { (mg/dl) }\end{array}$ & $\begin{array}{l}\text { HDL-cholesterol } \\
\text { (mg/dl) }\end{array}$ & $\begin{array}{l}\text { LDL-cholesterol } \\
(\mathrm{mg} / \mathrm{dl})\end{array}$ \\
\hline Control & $72.75 \pm 3.52^{\mathrm{c}}$ & $61.75 \pm 2.75^{\mathrm{cd}}$ & $38.75 \pm 2.46^{\mathrm{a}}$ & $21.65 \pm 3.29^{c}$ \\
\hline Paracetamol (2 g/kg) & $110.5 \pm 4.97^{\mathrm{a}}$ & $103.25 \pm 7.19^{\mathrm{a}}$ & $23.75 \pm 1.79^{\mathrm{e}}$ & $66.1 \pm 7.39^{a}$ \\
\hline Thyme oil (250 mg/kg) & $68.75 \pm 2.39^{\text {cd }}$ & $56.75 \pm 2.52^{\text {cd }}$ & $25.75 \pm 1.43 \mathrm{~d}^{\mathrm{e}}$ & $31.65 \pm 2.18^{\mathrm{bc}}$ \\
\hline Thyme oil (500 mg/kg) & $61.5 \pm 3.32^{\mathrm{d}}$ & $52.5 \pm 5.20^{\mathrm{d}}$ & $32.25 \pm 1.37 \mathrm{~b}^{\mathrm{c}}$ & $18.75 \pm 1.60^{c}$ \\
\hline Thyme oil (250 mg/kg)+Paracetamol (2 g/kg) & $101.25 \pm 3.3^{\mathrm{a}}$ & $91.75 \pm 3.30^{\mathrm{a}}$ & $28.5 \pm 2.78^{\mathrm{cd}}$ & $54.4 \pm 4.91^{\mathrm{a}}$ \\
\hline Thyme oil $(500 \mathrm{mg} / \mathrm{kg})+$ Paracetamol $(2 \mathrm{~g} / \mathrm{kg})$ & $85.25 \pm 2.71^{b}$ & $78.75 \pm 2.17^{b}$ & $30.75 \pm 1.25^{\mathrm{bc}}$ & $38.75 \pm 3.3^{3 b}$ \\
\hline Silymarin (100 mg/kg)+Paracetamol (2 g/kg) & $75.5 \pm 2.46^{c}$ & $66.25 \pm 2.56^{c}$ & $35.5 \pm 1.32^{\mathrm{ab}}$ & $26.75 \pm 3.20^{\mathrm{bc}}$ \\
\hline
\end{tabular}

Values are represented as Mean \pm SE $(n=5)$. Means within the same column carrying different superscripts are significant at $(p<0.05)$. 


\section{Journal of Pharmacology \& Clinical Research}

The co-treatment of thymus oil and paracetamol produced a significant decrease in cholesterol, triglycerides, LDL-cholesterol and significant increase in HDL-cholesterol concentrations in

\section{Hepatic and Renal Lipid Peroxidation and Antioxidant Status}

Table 4: Hepatic and renal tissue antioxidant markers of thymus oil (250 and $500 \mathrm{mg} / \mathrm{kg} \mathrm{BW}$ ) and/or paracetamol (2 g/kg BW) treated groups.

\begin{tabular}{|c|c|c|c|c|}
\hline Groups & Organ & MDA (nmol/g.tissue) & SOD (U/g.tissue) & CAT (U/g.tissue) \\
\hline Control & Liver & $42.03 \pm 2.41^{\mathrm{d}}$ & $38.09 \pm 1.76^{\mathrm{a}}$ & $83.39 \pm 2.18^{\mathrm{a}}$ \\
& Kidney & $123.75 \pm 2.73^{\mathrm{de}}$ & $76.66 \pm 2.69^{\mathrm{a}}$ & $55.07 \pm 2.26^{\mathrm{a}}$ \\
\hline \multirow{2}{*}{ Paracetamol $(2 \mathrm{~g} / \mathrm{kg})$} & Liver & $85.46 \pm 2.82^{\mathrm{a}}$ & $18.84 \pm 1.11^{\mathrm{d}}$ & $57.45 \pm 2.01^{\mathrm{d}}$ \\
& Kidney & $232.30 \pm 6.97^{\mathrm{a}}$ & $39.92 \pm 1.20^{\mathrm{d}}$ & $31.54 \pm 1.89^{\mathrm{c}}$ \\
\hline \multirow{2}{*}{ Thyme oil $(250 \mathrm{mg} / \mathrm{kg})$} & Liver & $39.73 \pm 1.73^{\mathrm{d}}$ & $36.04 \pm 1.41^{\mathrm{a}}$ & $81.08 \pm 2.73^{\mathrm{a}}$ \\
\hline \multirow{2}{*}{ Thyme oil $(500 \mathrm{mg} / \mathrm{kg})$} & Kidney & $118.66 \pm 3.14^{\mathrm{e}}$ & $71.54 \pm 0.81^{\mathrm{a}}$ & $54.75 \pm 2.05^{\mathrm{a}}$ \\
\hline Thyme oil $(250 \mathrm{mg} /$ & Liver & $39.26 \pm 1.94^{\mathrm{d}}$ & $35.62 \pm 1.57^{\mathrm{ab}}$ & $79.97 \pm 1.42^{\mathrm{a}}$ \\
$\mathrm{kg})+$ Paracetamol $(2 \mathrm{~g} / \mathrm{kg})$ & Liver & $67.53 \pm 1.87^{\mathrm{b}}$ & $22.72 \pm 1.34^{\mathrm{cd}}$ & $53.48 \pm 1.02^{\mathrm{a}}$ \\
\hline Thyme oil $(500 \mathrm{mg} /$ & Kidney & $205.94 \pm 2.61^{\mathrm{b}}$ & $45.50 \pm 1.16^{\mathrm{c}}$ & $63.51 \pm 1.05^{\mathrm{c}}$ \\
$\mathrm{kg})+$ Paracetamol $(2 \mathrm{~g} / \mathrm{kg})$ & Liver & $56.49 \pm 1.40 \mathrm{c}$ & $26.61 \pm 1.20^{\mathrm{c}}$ & $38.75 \pm 1.47^{\mathrm{b}}$ \\
\hline Silymarin $(100 \mathrm{mg} /$ & Kidney & $183.56 \pm 5.11^{\mathrm{c}}$ & $51.08 \pm 1.92^{\mathrm{b}}$ & $70.21 \pm 1.87^{\mathrm{b}}$ \\
$\mathrm{kg})+$ Paracetamol $(2 \mathrm{~g} / \mathrm{kg})$ & Liver & $45.03 \pm 2.11^{\mathrm{d}}$ & $31.61 \pm 0.99^{\mathrm{b}}$ & $43.30 \pm 1.39^{\mathrm{b}}$ \\
\hline
\end{tabular}

Values are represented as Mean \pm SE $(n=5)$. Means within the same column carrying different superscripts are significant at $(p<0.05)$.

MDA, malondialdehyde; SOD, superoxide dismutase; CAT, catalase.

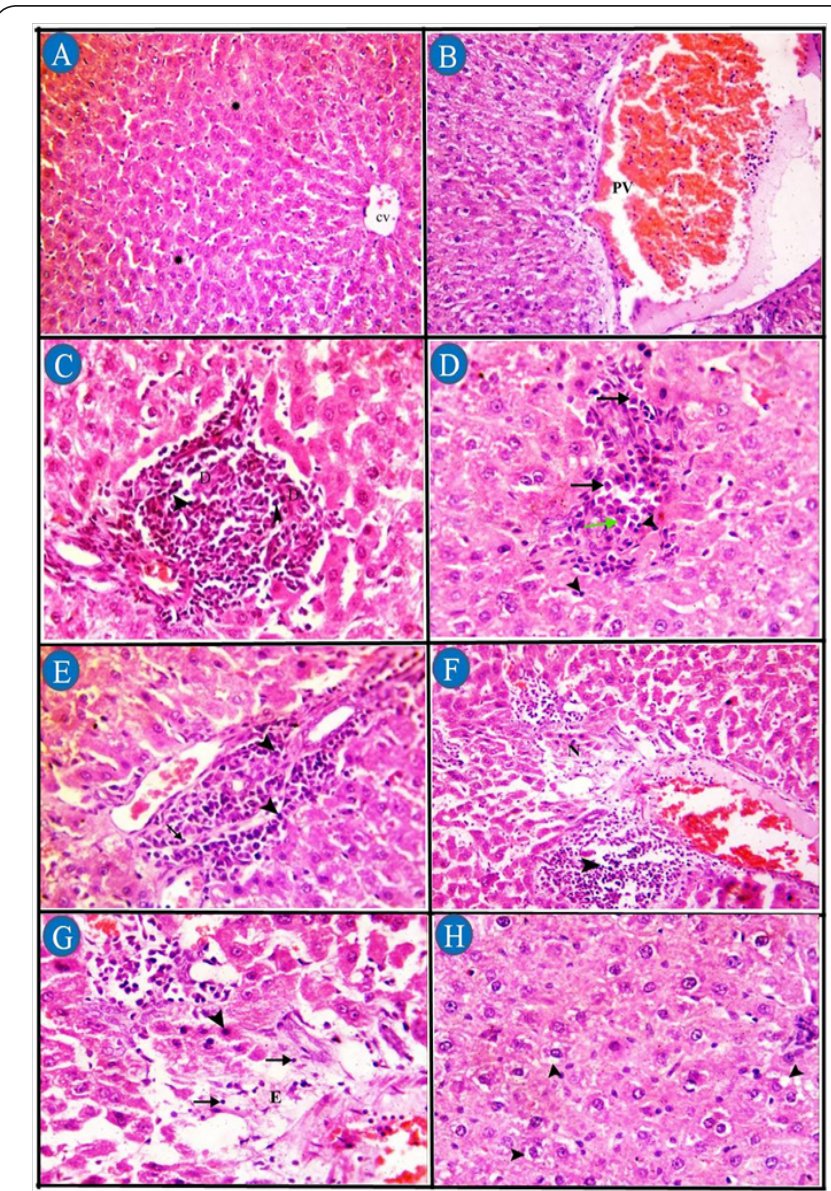

Figure 1: Representative photomicrographs of livers from thymus oil and/or paracetamol-treated groups (sections stained with H\&E). Group I: control (A), Group II: (B,C), Group III (D), Group IV (E), Group V (F), Group VI (G) and Group VII (H).

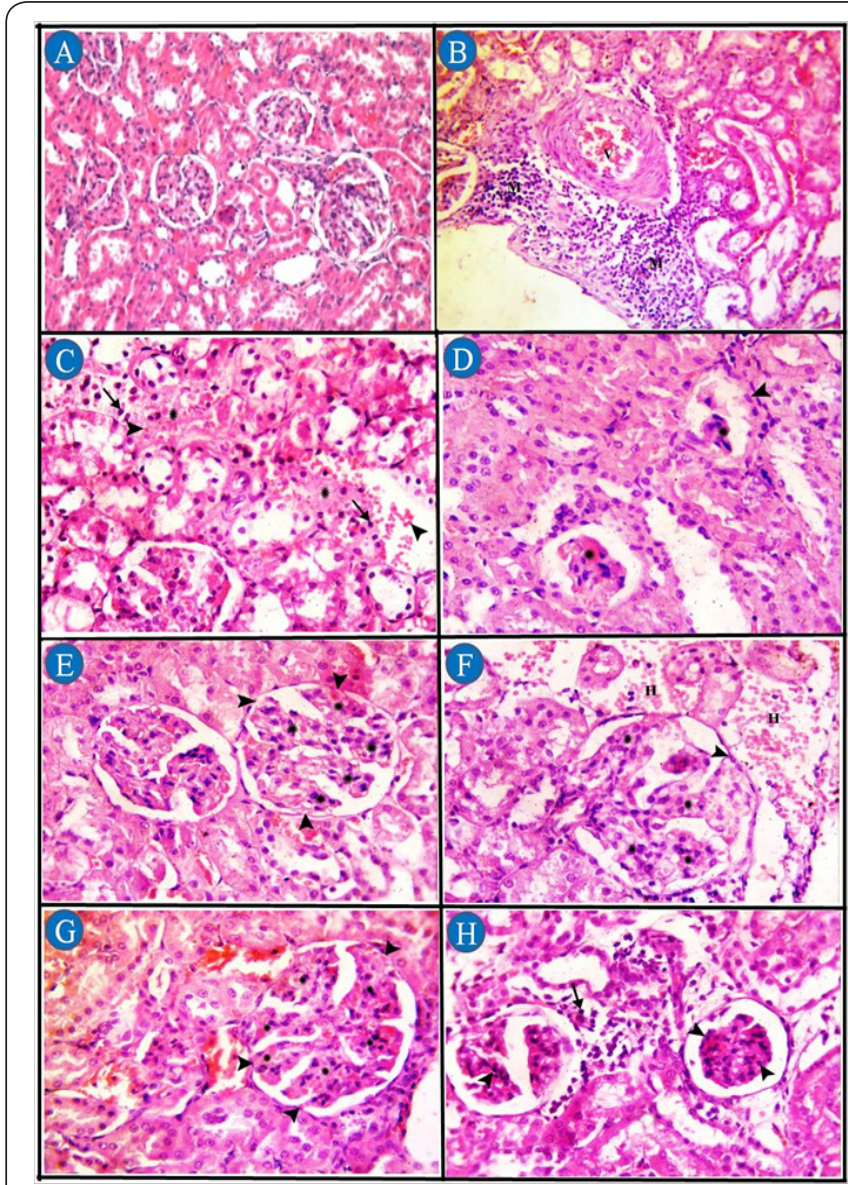

Figure 2: Representative photomicrographs of kidneys from thymus oil and/or paracetamol-treated groups (sections stained with H\&E). Group I: control (A), Group II: (B,C), Group III (D), Group IV (E), Group V (F), Group VI (G) and Group VII (H). 
The effects of the administration of thymus oil on the levels of liver and renal MDA and the activities of SOD and CAT in paracetamol-treated rats were recorded in Table 4. Paracetamol treatment brought about a significant depletion of SOD and CAT with increased MDA levels. Co-treatment with thymus oil significantly elevated the activity of both CAT and SOD content with marked decrease in the MDA level in hepatic and renal tissues when compared with paracetamol treated rat.

\section{Histopathology of Hepatic and Renal Tissues}

In the histopathological studies in hepatic and renal tissues, protective effects effect with slight degenerative changes were observed in rats administered thymus oil with paracetamol (Figures 1 \& 2). The liver of control group, no histopathological alteration and normal histological appearance of central vein (CV) and hepatic cords (asterisk) were recorded (Figure 1A). Group II, congestion and dilatation of portal vein (PV) (Figure 1B), area of hepatocytes necrosis characterized by loss of architecture and replaced by necrotic debris (D) and aggregates of mononuclear inflammatory cells (arrow head) (Figure 1C). In group III, a small aggregate of mononuclear inflammatory cells mainly lymphocytes (arrow head), plasma cells (arrow) and fewer macrophages (green arrow) in-between hepatocytes (Figure 1D). In group IV, aggregates of mononuclear inflammatory cells mainly lymphocytes (arrow) and macrophages (arrow head) in portal area (Figure 1E). In group $\mathrm{V}$, periportal aggregates of mononuclear inflammatory cells with necrosis of the surrounding hepatocyes $(\mathrm{N}$ ) (Figure 1F). In group VI, necrotic hepatocytes characterized by loss of cellular detail with hypereosinophilic cytoplasm and pyknotic nuclei (arrow head); and loss of architecture, replaced by edema (E) and small numbers of mononuclear inflammatory cells (arrow) (Figure 1G). In group VII, normal histological appearance with mild vacuolar and hydropic degeneration (arrow head) of few hepatocytes (Figure 1H).

The kidney of control group, no histopathological alteration and the normal histological structure of the glomeruli and tubules at the cortex were recorded (Figure 2A). Group II, congestion of the renal blood vessel (V) with perivascular aggregates of mononuclear inflammatory cells (M) (Figure 2B), areas of lytic necrosis characterized by loss of architecture and replaced by edema (asterisk), erythrocytes (arrow head) and small numbers of mononuclear inflammatory cells(arrow) (Figure 2C). In group III, shrinkage and necrosis of the glomerular tufts (asterisk) with hypertrophy of parietal epithelium of Bowman's capsule (arrow head) (Figure 2D). In group IV, hypersegmentation of glomerular tufts (asterisk) with adhesions (synechiae) between Bowman's capsule and glomerular tufts (arrow head) (Figure 2E). In group V, hyper segmentation of glomerular tufts (asterisk) with adhesions between glomerular tufts and Bowman's capsule (arrow head), also periglomerular hemorrhages $(\mathrm{H})$ were detected (Figure 2F). In group VI, hypersegmentation of glomerular tufts (asterisk) with adhesions (synechiae) between Bowman's capsule and glomerular tufts (arrow head)
(Figure 2G). In group VII, coagulative necrosis of mesangial/ endothelial cells characterized by retention of tuft architecture, hypereosinophilic cytoplasm, pyknosis (arrow head) and periglomerular infiltrates of mononuclear inflammatory cells (arrow) (Figure 1H).

\section{Discussion}

The results reflected the hepato-renal damage in the paracetamol induced hepato-renal toxicity. These observed elevations in paracetamol induced liver and kidney damage can be attributed to the release of enzymes from the cytoplasm into the blood circulation after the rupture of plasma membrane and cellular damage. The hepatoprotective effect of the two doses of thymus oil was shown by the decreases in the activities of ALT and AST. This is an indication of stabilization of plasma membrane as well as repair of hepatic tissue damage caused by paracetamol. The reversal of increased serum enzymes in paracetamol induced liver damage by thymus oil may be due to the prevention of the leakage of intracellular enzymes by its membrane stabilizing activity. Acting as a stabilizing agent, Thymus oil increased the stability of membrane and simultaneously attenuated the intracellular leakage of enzymes. This is in agreement with the commonly accepted view that serum levels of transaminases return to normal with the healing of hepatic parenchyma and the regeneration of hepatocytes [32].

Paracetamol is effective and safe in therapeutic doses, but acute or cumulative doses of the drug may induce renal tubular necrosis in both humans and laboratory animals [33]. Increases in serum urea and creatinine levels are an important marker of renal toxicity. Kidney disease and function disorders may occur as a result of serum urea accumulation exceeding its clearance rate. Similarly, increases in plasma creatinine levels are considered a nephron function disorder [34]. An overdose of paracetamol causes many metabolic disturbances including an increase in serum urea and creatinine [4]. In the present study, serum urea and creatinine levels in the groups treated with thymus oil and paracetamol were significantly reduced compared with the paracetamol treated group.

Thymus oil produced a significant decrease in cholesterol, triglycerides, LDL-cholesterol and significant increase in HDLcholesterol concentrations in serum of thymus oil treated groups than recorded in control group. Also, improve the lipid profile after paracetamol toxicity. These results were consistent with those obtained by [35] who recorded that paracetamol overdose caused significant increase in total cholesterol, serum triglycerides, low density lipoprotein, total bilirubin with a reduction of albumin and high density lipoprotein cholesterol. The reduction in albumin and protein concentrations and increase in triglyceride concentration is attributed to the initial damage produced and localized in the endoplasmic reticulum which results in the loss of $\mathrm{P} 450$ leading to its functional failure with a decrease in protein synthesis and accumulation of triglycerides leading to fatty liver. The rise in protein and albumin 
concentrations and decrease in triglyceride concentration suggests the stabilization of endoplasmic reticulum leading to protein synthesis and the anti-hyperlipidemic effect of thymus oil. The mechanism of hypolipedemic effct of medicinal plant may be due to the inhibition of dietary lipid absorption in the intestine or its production by liver or stimulation of the biliary secretion of cholesterol and cholesterol excretion in the faeces [36]. Also, hypolipedemic effect of medicinal plant may be due to the inhibition of glycation lipoproteins, enzymes and proteins that involve lipid and lipoprotein metabolism [37].

There is a growing interest in the antioxidant properties of many herbs and spices that were reported to be effective in retarding the process of lipid peroxidation in oils and fatty acids [38-40]. MDA is known as a secondary product of lipid peroxidation and is used as a marker of tissue damage resulting from many chain reactions $[41,42]$. Hepatic and renal oxidative stress is induced by increases in lipid peroxidation products (e.g., MDA) and decreases in antioxidant defensive enzyme activities [43]. The previous study shows that paracetamol induced rats had significant lipid hydroperoxides in hepatic and kidney tissues [44]. Increased MDA levels in liver and kidney tissues have long been known to cause functional degradation; therefore, the degradation of vital tissue leading to complications may be indirectly due to increased oxidative stress [45].

In our study, the administration of paracetamol $(2 \mathrm{~g} / \mathrm{kg})$ caused significant elevations in hepatic and renal MDA levels compared to the control group. Alternatively, the MDA levels in the thymus oil $250 \mathrm{mg} / \mathrm{kg}+$ paracetamol and thymus oil $500 \mathrm{mg} /$ $\mathrm{kg}+$ paracetamol groups were significantly lower compared to the paracetamoltreated group. Our results showed that thymus oil reduced MDA levels in the hepatic and renal tissues. Thymus oil provides a satisfactory protection against paracetamol induced lipid peroxidation. Enzymatic antioxidants play an important role by protecting the cells exposed to oxidative damage. SOD is an important enzyme that converts the superoxide radical to molecular oxygen $\left(\mathrm{O}_{2}\right)$ and hydrogen peroxide $\left(\mathrm{H}_{2} \mathrm{O}_{2}\right)$ [46]. CAT is an enzyme that converts $\mathrm{H}_{2} \mathrm{O}_{2}$ to $\mathrm{O}_{2}$ and water, and is generally located in the intracellular peroxisomes [47]. The activities of the SOD and CAT enzymes were significantly reduced in the paracetamol induced hepato-renal toxicity group. In this study, paracetamol significantly reduced the antioxidant activities of SOD and CAT, in the hepatic and renal tissues in comparison with the control group. Pre-treatment with thymus oil ( 250 or $500 \mathrm{mg}$ / $\mathrm{kg}$ ) significantly attenuated the paracetamol induced decrease in antioxidant enzyme activities observed in rat hepatic and renal tissues. Thymus oil treatment also significantly reduced paracetamol induced oxidative stress levels. The mechanism of this effect is considered to be due to the capability of the hydroxyl groups located on the fifth and eighth positions in the paracetamol molecule to directly eliminate free radicals [48].

Additionally, it has been determined that thymus oil indirectly suppresses oxidative stress by regulating antioxidant enzyme activities [49]. Similarly, many studies have reported that thymus oil treatment protects tissues against oxidative stress and induces an increase in antioxidant enzyme activities $[45,50]$.

\section{Conclusion}

The protective property of thymus oil is further confirmed by significant improvement of the liver and kidney architecture. The present study suggests that the thymus oil has a tremendous potential to reverse the hepato-renal changes induced by paracetamol back to normal via its antioxidant activity.

\section{Acknowledgment}

The authors wish to thank Prof. Dr: Shawky Mostafa (Department of pathology, Faculty of Veterinary Medicine, Benha University, Egypt) for his comments on histopathological study.

\section{References}

1 AO Ogbera, O Dada, F Adeyeye, PI Jewo (2010) Complementary and alternative medicine use in diabetes mellitus. West Afr J Med 29(3): 158-162.

2 M Hasan, AA Khan (1997) Development of gastroenterology in Bangladesh. J Gastroenterol Hepatol 12(5) S13-S14.

3 E Bukhsh, SA Malik, SS Ahmad, S Erum (2014) Hepatoprotective and hepatocurative properties of alcoholic extract of Carthamus oxyacantha seeds. Afr J Plant Sci 8(1): 34-41.

4 V Srinivasan, R Panneerselvam, S Gunasekaran, S Palani (2014) Ethanolic extract of Melia azadirachta against acetaminophen induced nephrotoxicity. Int J PharmTech Res 6(1): 70-79.

5 C Zhao, S Duquet, Y-X Zhou (1998) Effects of combined use of diallyl disulfide and $\mathrm{N}$-acetyl-cysteine on acetaminophen hepatotoxicity in $\beta$-naphthoflavone pretreated mice. World J Gastroenterol. 4(2): 112116.

6 JA Hinson, AB Reid, SS Mc Cullough, LP James (2004) AcetaminophenInduced Hepatotoxicity: Role of Metabolic Activation, Reactive Oxygen/Nitrogen Species, and Mitochondrial Permeability Transition. Drug Metab Rev 36(3-4): 805-822.

7 AM Larson (2007) Acetaminophen hepatotoxicity. Clin Liver Dis 11(3): 525-548.

8 LI Roberts (2001) Analgesic-antipyretic and antiinflammatory agents and drugs employed in the treatment of gout, Goodman \& Gilman's the pharmacological basis of therapeutics 687-731.

9 P. Abraham (2005) Vitamin C may be beneficial in the prevention of paracetamol-induced renal damage. Clin Exp Nephrol 9(1): 24-30.

10 PK Visen, B Shukla, GK Patnaik, BN Dhawan (1993) Andrographolide protects rat hepatocytes against paracetamol-induced damage. J Ethnopharmacol 40(2): 131-136.

11 I Rasooli, MB Rezaei, A Allameh (2006) Ultrastructural studies on antimicrobial efficacy of thyme essential oils on Listeria monocytogenes. Int J Infect Dis 10(3): 236-241.

12 K Sasaki, K Wada, Y Tanaka, T Yoshimura, K Matuoka, et al. (2005) Thyme (Thymus vulgaris L.) leaves and its constituents increase the activities of xenobiotic-metabolizing enzymes in mouse liver. J Med Food 8(2): 184-189.

13 M Höferl, S Krist, G Buchbauer (2006) Chirality influences the effects of linalool on physiological parameters of stress. Planta Med 72(13): 1188-1192. 
$14 \mathrm{H}$ Dorman, S Deans (2000) Antimicrobial agents from plants: antibacterial activity of plant volatile oils. J Appl Microbiol 88(2): 308316.

15 R Amarowicz, Z Żegarska, R Rafałowski, RB Pegg, M Karamać, et al. (2009) Antioxidant activity and free radical-scavenging capacity of ethanolic extracts of thyme, oregano, and marjoram. Eur J Lipid Sci Technol 111(11): 1111-1117.

16 MS Reshi, S Shrivastava, A Jaswal, N Sinha, C Uthra, et al. (2017) Gold nanoparticles ameliorate acetaminophen induced hepato-renal injury in rats. Exp Toxicol Pathol 69(4): 231-240.

17 R Grespan, RP Aguiar, FN Giubilei, RR Fuso, MJ Damião, et al. (2014) Hepatoprotective effect of pretreatment with Thymus vulgaris essential oil in experimental model of acetaminophen-induced injury. Evidence Based Complementary and Alternative Medicine 2014(2014): 954136.

18 F Fraschini, G Demartini, D Esposti (2002) Pharmacology of silymarin. Clin Drug Investigation 22(1): 51-65.

19 S Reitman, S Frankel (1957) A colorimetric method for the determination of serum glutamic oxalacetic and glutamic pyruvic transaminases. American Journal of Clinical Pathology 28(1): 56-63.

20 M Schmidt, J Eisenburg (1975) Serum bilirubin determination in newborn infants. A new micromethod for the determination of serum of plasma bilirubin in newborn infants. Fortschritte der Medizin 93(30): 1461-1466.

21 B Doumas, H Biggs (1975) Colourimetric determination of total protein in serum or plasma. Clin. Chem 21(8): 1159-1166.

22 BT Doumas, WA Watson, HG Biggs (1971) Albumin standards and the measurement of serum albumin with bromcresol green. Clin Chim Acta 31(1): 87-96.

23 P Trinder (1969) Determination of blood glucose using an oxidaseperoxidase system with a non-carcinogenic chromogen. J Clin Pathol 22(2): 158-161

24 J Schirmeister, H Willmann, H Kiefer (1964) Critical Evaluation of Plasma Creatinine as a test of glomerulus filtrate. Verh Dtsch Ges Inn Med 70: 678-681.

25 LB Foster, JM Hochholzer (1971) A single-reagent manual method for directly determining urea nitrogen in serum. Clin Chem 17(9): 921925

26 SS Shah, GB Shah, SD Singh, PV Gohil, K Chauhan, et al. (2011) Effect of piperine in the regulation of obesity-induced dyslipidemia in high-fat diet rats. Indian J Pharmacol 43(3): 296-299.

27 R Johnson, P McNutt, S MacMahon, R Robson (1997) Use of the Friedewald formula to estimate LDL-cholesterol in patients with chronic renal failure on dialysis. Clin Chem 43(11): 2183-2184.

28 H Aebi (1984) Catalase in vitro. Methods Enzymol 105: 121-126.

29 M Nishikimi, N Appaji Rao, K Yagi (1972) The occurrence of superoxide anion in the reaction of reduced phenazine methosulfate and molecular oxygen. Biochem Biophys Res Commun 46(2): 849-854.

30 H Ohkawa, N Ohishi, K Yagi (1979) Assay for lipid peroxides in animal tissues by thiobarbituric acid reaction. Anal Biochem 95(2): 351-358.

31 KS Suvarna, C Layton, JD Bancroft (2012) Bancroft's Theory and Practice of Histological Techniques E-Book. Elsevier Health Sciences.

32 MI Thabrew, PD Joice, W Rajatissa(1987) A comparative study of the efficacy of Pavetta indica and Osbeckia octandra in the treatment of liver dysfunction. Planta Medica 53(3): 239-241.

33 Adam GO, Rahman MM, Lee SJ, Kim GB, Kang HS, et al. (2016) Hepatoprotective effects of Nigella sativa seed extract against acetaminophen-induced oxidative stress. Asian Pac J Trop Med 9(3): 221-227.
34 MI Yousef, SA Omar, MI El-Guendi, LA Abdelmegid (2010) Potential protective effects of quercetin and curcumin on paracetamol-induced histological changes, oxidative stress, impaired liver and kidney functions and haematotoxicity in rat. Food Chem Toxicol 48(11): 32463261.

35 A Elkomy, M Aboubakr, A Soliman, A Abdeen, A Abdelkader, et al. (2016) Paracetamol induced hepatic toxicity and amelioration by cinnamon in rats. International Journal of pharmacology and toxicology 4(2): 187190.

36 A Garjani, F Fathiazad, A Zakheri, NA Akbari, Y Azarmie, et al. (2009) The effect of total extract of Securigera securidaca L. seeds on serum lipid profiles, antioxidant status, and vascular function in hypercholesterolemic rats. J Ethnopharmacol 126(3): 525-532.

37 Harris CS, Beaulieu LP, Fraser MH, McIntyre KL, Owen PL, et al. (2011) Inhibition of advanced glycation end product formation by medicinal plant extracts correlates with phenolic metabolites and antioxidant activity. Planta Med 77(02): 196-204.

38 M Namiki (1990) Antioxidants/antimutagens in food. Crit Rev Food Sci Nutr 29(4): 273-300.

39 J Pokorný (1991) Natural antioxidants for food use. Trends Food Sci Technol 2: 223-227.

40 Pin-Der Duh, Gow-Chin Yen (1997) Antioxidant efficacy of methanolic extracts of peanut hulls in soybean and peanut oils. J Am Oil Chem Soc 74(6): 745 .

41 I Gülçin (2012) Antioxidant activity of food constituents: an overview. Arch Toxicol 86(3): 345-391.

42 I Gulcin, S Beydemir (2013) Phenolic compounds as antioxidants: carbonic anhydrase isoenzymes inhibitors. Mini Rev Med Chem 13(3): 408-430.

43 A Ghosh, PC Sil (2007) Anti-oxidative effect of a protein from Cajanus indicus L against acetaminophen-induced hepato-nephro toxicity. J Biochem Mol Biol 40(6): 1039-1049.

44 M Cekmen, Y Ilbey, E Ozbek, A Simsek, A Somay, et al. (2009) Curcumin prevents oxidative renal damage induced by acetaminophen in rats. Food Chem Toxico 47(7): 1480-1484

45 G Pushpavalli, C Veeramani, KV Pugalendi (2010) Influence of chrysin on hepatic marker enzymes and lipid profile against D-galactosamineinduced hepatotoxicity rats. Food Chem Toxicol 48(6): 1654-1659.

46 I Gülçin, E Bursal, MH Şehitoğlu, M Bilsel, AC Gören (2010) Polyphenol contents and antioxidant activity of lyophilized aqueous extract of propolis from Erzurum, Turkey. Food Chem Toxicol 48(8-9): 2227 2238.

47 A Ramos, A Correia, S Antunes, F Gonçalves, B Nunes (2014) Effect of acetaminophen exposure in Oncorhynchus mykiss gills and liver: detoxification mechanisms, oxidative defence system and peroxidative damage. Environ Toxicol Pharmacol 37(3): 1221-1228.

48 EM Mantawy, WM El-Bakly, A Esmat, AM Badr, E El-Demerdash (2014) Chrysin alleviates acute doxorubicin cardiotoxicity in rats via suppression of oxidative stress, inflammation and apoptosis. Eur J Pharmacol 728: 107-118.

49 MU Rehman, M Tahir, AQ Khan, R Khan, A Lateef, et al. (2013) Chrysin suppresses renal carcinogenesis via amelioration of hyperproliferation, oxidative stress and inflammation: plausible role of NF- $\kappa$ B. Toxicol Lett 216(2-3): 146-158

50 J Sathiavelu, GJ Senapathy, R Devaraj, N Namasivayam (2009) Hepatoprotective effect of chrysin on prooxidant-antioxidant status during ethanol-induced toxicity in female albino rats. J Pharm Pharmacol 61(6): 809-817. 
(C) This work is licensed under Creative BY DOI: $10.19080 / J P C R .2017 .04 .555637$

\section{Your next submission with Juniper Publishers will reach you the below assets}

- Quality Editorial service

- Swift Peer Review

- Reprints availability

- E-prints Service

- Manuscript Podcast for convenient understanding

- Global attainment for your research

- Manuscript accessibility in different formats ( Pdf, E-pub, Full Text, Audio)

- Unceasing customer service

Track the below URL for one-step submission https://juniperpublishers.com/online-submission.php 